\title{
Resumption of Single Stock Futures (SSFs) with Stringent Regulations and their Impact on the Risk Characteristics of the Underlying Stocks
}

\author{
Imran Riaz Malik ${ }^{1}$, Attaullah Shah ${ }^{2}$
}

\begin{abstract}
During the stock market turmoil and later on in the year 2008, the Securities and Exchange Commission of Pakistan (SECP) suspended trading in futures products at the Karachi Stock Exchange (KSE) due to their proven destabilizing role in Global Financial Crises (GFC). On July 27th 2009, the Single Stock Futures (SSFs) were re-launched with stringent regulations for their trading in stock market. In this study, an attempt is made to identify changes in the volatility dynamics of underlying stocks after resumption of SSFs in KSE with tighter regulations than before and whether stringent regulations are justified or not. Specifically, the study decomposes volatility into systematic and unsystematic risk components and investigates the inherent changes in the underlying stocks' volatility subsequent to the resumption of SSFs. The findings suggest that the decrease in the systematic and unsystematic risk cannot be attributed to the firms' contract listing, but contemporaneous market, industry or macroeconomic changes. The findings may imply that stringent regulations are unjustified, which may reduce the liquidity and efficiency of the market and do no good to the market.
\end{abstract}

Key words: Single Stock Futures, CAPM, GJR-GARCH, GED and Student's t

\section{Introduction}

Since their introduction in 70's, the potential impact of futures on the underlying spot market has received a great deal of attention from the stakeholders of stock markets. Investors' behavior remained an important aspect while observing impact of futures markets. Till date, the researchers could not establish consensus on investors' role in stabilizing or destabilizing these impacts. A renowned hypothesis about the introduction of futures markets is that noise traders play an important role in destabilizing (in terms of enhancement of volatility) the underlying market. This study investigates noise trading with respect to the inhibiting or promoting abilities of the futures markets. In the context of behavioral finance, theoretical arguments emphasize upon the relationship between observed price and the fundamental value

1 Corresponding Author: Assistant Professor, IQRA University, Islamabad. Email: imran.malik@ iqraisb.edu.com

2 Assistant Professor, Institute of Management Sciences, Peshawar. Email: attaullah.shah@imsciences. edu.pk 
of the traded security. The difference is mostly attributed to the microstructure related noise (hereafter systematic risk) and noise trading (hereafter unsystematic risk) in the market. Mazouz and Bowe (2006) point out that the difference between the observed and fundamental values is attributed to systematic and unsystematic risk. Earlier, Black (1986) claimed that noise is an important part of financial markets. Noise trading increases the liquidity of the market however make it imperfect. De Long, Shleifer, Summers, and Waldman (1990a) assert that the unpredictability of noise traders' philosophy is the reason for increased risk in the asset prices which simultaneously influences the deterrence of rational arbitrageurs. Consequently, the risk-averse arbitrageurs do not take positions to exploit the arbitrage opportunities. For such a reason, the asset prices move away from the fundamental values, even in the absence of fundamental risk. Sometimes, arbitrageurs attempt to move the prices close to their fundamental values through arbitrage mechanism by shorting a substitute stock. The presence of corresponding Single Stock Futures (SSFs) helps arbitrageurs dealing with the issue of availability of perfect substitute stock, which helps arbitrageurs in dealing with the systematic risk. Arbitrageurs may also face risk from noise traders because of the luring features of SSFs, which might be the target of noise traders. In this study, an attempt has been made to identify the impact of the resumption of SSFs on the systematic and unsystematic risks of the underlying stocks. Specifically, the objective of this study is to identify the impact of SSFs' resumption on the stability (systematic and unsystematic risk) of Pakistan's stock market.

In Pakistan, SSFs were introduced in July, 2001, when trading in 10 stocks was initiated. The number of SSFs listed stocks kept on increasing and decreasing based on the eligibility criteria regulated by Securities and Exchange Commission of Pakistan (SECP). During the global economic crisis of 2008, the value of KSE-100 decreased by $50 \%$, after which it was banned for few months. Trading in SSFs was also discontinued. Futures markets were also blamed for hyper volatility witnessed by the market (Khan, 2006; Ahmad, Shah, \& Shah 2010; Naz, 2011). Later on, trading in SSFs was resumed in in 18 stocks in July, 2010 with stringent regulations. There are few differences in regulations ${ }^{3}$ for these resumed SSFs from the initially issued SSF contracts back in 2001. Keeping the foregoing discussion in view, it is necessary to explore that whether stringent regulations of newer SSFs have played any role in stabilizing the market by reducing its volatility.

The study derives its significance from the following two aspects. First, the debate on the impact of SSFs on the underlying stock market dynamics has intensified in

3 The significant regulation changes which bring more control and lesser value at risk are as follows: first, the bank or cash margin guarantee is increased from 50pc to 100pc which depicts that trading in SSFs is difficult than before. Second, concentration margin is applicable instead of special margin, and third, the exchange will retain the marked-to-market profit instead of distributing it to stakeholders. 
Pakistan's market after the market crashed in 2005 and later in 2008. Like other economies, future markets are blamed for their persistent hyper-volatility in KSE as well. This situation makes it imperative to study the impact of futures market on its underlying stock market. Second, in April, 2012, in order to strengthen the stock market of Pakistan, SECP approved to regulate index option contracts according to the best international regulatory practices. The findings of this study would be helpful to policy makers in revising and formulating regulations of the futures markets in Pakistan.

This study contributes to the literature of financial economics in the following aspects. It improves the methodology of Mazouz and Bowe (2006) by adding AR(1) term to capture the market inefficiencies while improving the explanatory power of the model, the use of Generalized Error Distribution (GED), and student's $t$ along with normal distribution to capture the proclaimed ${ }^{4}$ fat tails of the financial time series data in the context of an emerging economy.

The rest of the paper is organized as follows: Section 2 presents literature on the stabilizing and destabilizing impacts of futures markets around the globe. Section 3 explains the data and methodology. Section 4 discusses empirical analysis and results. Section 5 concludes the paper along with policy implications.

\section{Literature Review}

A number of studies have been conducted which evaluate the influence of derivatives' trading on stock markets during the recent decades. Although there are a number of factors that contribute to the volatility of stock prices, significant concern has been shown in theoretical and empirical studies which investigate the impact of derivatives trading on stock prices' volatility. Different conclusion statements observed to the same premise in an argument of effect of derivative trading on spot market volatility.

There are several studies that investigate the impact of futures markets on the volatility dynamics of underlying market. For example, in order to check the impact of introduction of options stock on the underlying, (Skinner 1989; Conrad 1989) decomposed volatility into systematic and unsystematic risk components, and reported that with the introduction of options on stocks, the systematic risk is not affected, while unsystematic risk has decreased. On the other hand, by using monthly returns data Martin and Senchak (1989) reported an increase in the systematic risk of the 20 Major Market Index (MMI). They attributed the increase in systematic risk to the use

4 Bollerslev (1987), Kaiser (1996) and Beine, Laurent and Lecourt (2000) suggested the use of Student's t distribution. On the other hand, Nelson (1991) and Kaiser (1996) recommended considering GED for such an instance. 
of controversial program trading. Also, Martin and Senchak (1991), by using daily returns data of stocks comprising the MMI checked the impact of introduction of derivatives on the underlying, with the use of control sample of 20 stocks, in order to mitigate the endogeneity bias. The results were consistent with their earlier study, i.e., on average an increase in the systematic risk in the 20 stock from MMI, while the non-MMI stocks show a little evidence of increase. So, the results remain robust across the use of improved methodology, and they affirm the presence of program trading in the future contracts of MMI. Vijh (1994) used S\&P 500 stocks and relatively matched non-index stocks, and reported on average significant increase in the systematic risk in the S\&P 500 stocks after listing of future contracts.

Following studies investigated the impact of trading in equity derivatives and their impact on volatility of underlying spot market. The empirical results of these studies could be divided into three categories. Some studies show increase in volatility when parallel derivative markets in action, other show no change, while few report decrease in volatility. For example, according to Schwert (1990), Harris (1989) and Damodaran (1990), there is a positive relationship between futures trading and volatility for the S\&P 500 index. Similarly, Bessembinder and Seguin (1992) reported positive relationship in volatility attributed to information based trading and negative relationship with information less trading activity. Furthermore, Elluceta and Lauente (2003), using non-parametric approach confirmed the results of Bessimender and Segiun (1992), that volatility in spot market is positively related to unexpected (new information component). (Lee \& Ohk 1992; Figlewskly 1981; and Brorsen 1991) rejected the hypothesis that future trading decreases spot price volatility. Like some others, Yang, Balyeat and Leatham (2005), affirm positive relationship between price volatility and unexpected component of future trading volume in commodity futures market. In an effort to predict spot market volatility, Kyriacou and Sarno (1999) established that futures volumes (contemporary and lags) of FTSE 100 were the reasons of spot market volatility in UK.

Unlike prior studies, Smith Jr. (1989) found that changes in S\&P stock index futures volume is independent of changes in volatility of S\&P500 index returns. Chang, Cheng, and Pinegar (1999) compared the introduction of Nikkei futures on OSE \& SIMEX, and showed that with the introduction of Nikkei futures on these two exchanges' different results were observed. They reported no change in volatility on SIMES but insignificant increase on OSE. Dennis and Sim (1999) provide-d Australian evidence of insignificant relationship between individual share futures on the spot market volatility in Sydney Future Exchange. While observing spot market volatility, Edwards (1988), Butterworth (2000), Hodgson and Nicholls (1991) and Becketti and Roberts (1990) reported that future trading in index showed insignificant 
reduction in spot price volatility. Board, Sandman, and Sutcliefe (2001) investigated the hypothesis that informed traders move from spot to future market, which results in destabilization in the form of reduction in trading volume. By using different statistical modeling, they found that the destabilization was not statistically significant.

On the other hand, Brown-Hruska and Kuserk (1995) reported negative relationship between spot price volatility and the stock index futures trading. Santoni (1987) found the similar results. Furthermore, Thenmozhi (2002) and Gupta and Kumar (2002) reported decrease in index volatility after introduction of futures by using simple various ratio test and OLS multiple regression analysis techniques.

Different other perspectives have also been presented on the issue of changes that occur due to introduction of equity derivatives. For example, according to Figlewski (1981), if introduction of equity derivatives increases the liquidity of the underlying stocks, then the prices should move towards their fundamental values as a result of enhanced information flow. Similarly, Demsetz, (1968) and Madhavan (2000) argued that market makers in the underlying market make use of equity derivatives. It enables them to hedge their exposure, and enhances turnaround on their inventories, which ultimately reduces the bid ask spread. On the other hand, some researchers assign different reasoning to the impact of derivatives on liquidity of underlying stocks. The information increase from the trading activities of less informed traders may have destabilizing impact on the market. Eventually, it impairs the ability of informed traders to extract the information regarding intrinsic value of the underlying stock, consequently reducing their ability to make better decisions. The destabilizing impact of increase in trading noise, resulted, will be more than the stabilizing impact of increased liquidity (Stein 1987; Dennis and Sim 1999). Ma and Rao (1988) argued that, uninformed traders show risk averse behavior, because of their inability to make errorless predictions. So, they are more inclined towards use to derivatives for their hedging intentions. Similarly, Gorton and Pennacchi (1993) argued that existence of future markets may increase the attractiveness and retainment of uninformed traders in the underlying market, because of the lower transaction costs. Also, it supports them in their hedging decisions using futures than making equivalent stock transactions. Information asymmetry in the bid ask spread may result in, as a result of this increase in the magnitude of uninformed traders in the spot and future markets. It is also possible that the increase in the uninformed activity may result in enhanced trading noise, which may delay the speed of incorporation of information in the stock prices. Glosten and Milgrom (1985) and Easley and O'hara (1987) argued that as a result of increase in uninformed traders in the market, the market makers will now trade with them as well. The market makers would be charging less information rent than they would, when they have to trade with more informed traders. 
Regarding Pakistan's market, there is little work done on impact of futures introduction on different aspects of spot market. In Pakistani Context, study conducted by Khan and Hijazi (2009) reported that introduction of SSFs have led to significant decrease in underlying spot market stock returns and decrease in volatility. Khan (2006) reported that future trading should not be blamed for increased spot market volatility in the year 2005, which led to market crash in KSE. Using (VECM) for causality and feedback relationship, he argued, that information incorporation in spot prices explains the future prices and not the vice versa. This study focused on the value and role of equity trading on volatility of Pakistan's stock market with the emphasis on capability of derivatives in predicting the spot prices. The GARCH model has been used to study the volatility in the corresponding spot and future markets and the relationship of volatility amongst them. Empirical results showed that spot prices lead the future prices in incorporation of information arrival. Earlier, Khan, Shah, and Abbas (2011) examine the impact of the introduction of SSFs on volatility dynamics of underlying stocks, and provide evidence in the context of Pakistan that change in volatility could not be attributed to the introduction of SSFs. Similarly, in another study, Khan and Abbas (2013) report decrease in systematic risk for both SSFs and non-SSFs for introduction episode. They only check the change in systematic risk. On the other hand, this study on resumption episode will add value to the literature on derivatives specifically in Pakistan's market by investigating the impact on systematic as well as unsystematic risk.

\section{Data and Methodology}

This study makes use of an event study methodology. While studying events, two approaches have extensively been used in order to investigate the impact of derivatives' trading on underlying stocks' volatility dynamics. First approach compares the change in volatility from pre and post period of the underlying event and second approach aims at cross-sectional comparison of the degree change across SSFs and Non-SSFs. Despite the fact that both approaches have mechanical compensation over one another, they need to congregate several circumstances to be consistent. The findings that the resumption of SSFs stimulates significant changes in systematic and unsystematic risk raise a question, as to whether the SSFs are the main reason for such changes or there are some other factors, which play role in influencing the beta coefficient. Argument could be made that there might be some other potential factors (market or industry specific macroeconomic conditions), which affect the change in systematic and unsystematic risk other than SSFs contracts' listings. Such influences could be studied by the use of control sample. In order to isolate the impact of resumption of SSFs from other factors, the study compares post listing changes in the systematic and unsystematic risk of SSFs with that of Non-SSFs. 
The underlying study employs both approaches to take care of robustness and differences in potential cross-sectional factors. Following econometric models are used to empirically prove the hypothesis of the study.

In order to measure, and identify the changes in the volatility of the underlying stock, the study employs CAPM as the mean equation and the GJR-GARCH as the variance equation of the model. To provide empirical evidence on the debate of performance of CAPM, Hussain, Obaid and Afridi (2011) used it for estimation of cost of equity capital by randomly selecting 45 companies listed on KSE. They reported that out of 45 companies, value of beta is found significant for 37 companies. They interpret that use of CAPM for measurement of beta is a useful tool for computing risk in the context of Pakistan. The volatility is divided ${ }^{5}$ into two components i.e., systematic and unsystematic risk. First, the measure of systematic risk i.e., beta is computed form the mean equation, and is compared in both SSFs and Non-SSFs, for pre to post periods. Second, GJR-GARCH $(1,1)$ specification is employed to check the variation in the error term (i.e. unsystematic risk).

\subsection{Data Description}

We use a sample of the SSFs and non-SSFs stocks. The non-SSF sample is taken in conformity with the SSFs stocks, on the basis of sector, firm size and trading volume. The sample period is comprised of the resumption episode. Since the futures were also blamed for stock market crash in 2008, the Six months daily and weekly closing prices' observations on each side of the event date are used to examine the effect of the resumption of SSFs contracts. The use of six months daily and weekly data for this study is due to the limitation that maximum nine months data was available for pre-period of resumption of SSFs. This is evident from the fact that trading in SSFs remained closed for only approximately eight months after the market crash. The data is collected from online database of "Business Recorder", a premier daily business newspaper. For market portfolio, daily and weekly KSE100 index is used, which is retrieved from "Yahoo finance" and daily and weekly prices of three-month $\mathrm{T}$ bill rates are used as a proxy for risk free rate.

\subsection{Capital Asset Pricing Model}

In the context of CAPM, the systematic and unsystematic risk of any financial time series data can be specified with the help of following equation of the model:

$$
R_{i, t}-R_{f, t}=\propto_{i}+\gamma\left(R_{i, t-1}-R_{f, t-1}\right)+\left(\beta_{i, b}+\beta_{i, c} D_{f u t}\right) R_{m, t}+\varepsilon_{i, t}
$$

5 This approach of decomposing risk into above mentioned two parts is widely used in the literature on options' listing and related matters (Mazouz and Bowe, 2006; Elfakhani EJ Chaudhury, 1995; Damodaran E⿱乛 Lim, 1991). 
Here, $R_{i, t}$ is the return on an individual stock $i$ at time, and $R_{f, t}$ is the risk free rate at time t. $\propto_{i}$ is the stock specific intercept term. The coefficients $\beta_{i, b}$ and $\beta_{i, c}$ represent the systematic risk before the resumption of futures, and change in systematic risk of respective stocks from pre to post trading period. The $\mathrm{p}$ value associated with will be used to make inference about any hypothesized statistically significant systematic risk change, following future contracts' listings. $D_{f u t}$ is the dummy variable, which is used to distinguish the pre to post future contracts' listing period. $R_{m, t}$ is the market return in excess to the risk free return, at time t. At the end, $\varepsilon_{i, t}$ is the error occurred for individual stock $i$ at time $t$, which represents error in prediction on the basis of this relationship. It is well established that financial time series data does not follow normal distribution. For which literature suggests use of non-normal distributions (e.g., Generalized Error Distribution (GED) and student's t distribution etc.). This study makes use of GED and student's t distribution to take care of non-normality of return series into account.

In order to check the variation in the error term, the following equation is used in the study.

$$
\varepsilon_{i, t}=\gamma_{i, t} h_{i, t}
$$

Here, $\gamma_{i, t} \sim \mathrm{N}$, t or GED

And,

$h_{i, t}^{2}=\varphi_{i, b}+\varphi_{i, c} D_{f u t}+\delta_{i, 1} \varepsilon_{i, t-1}^{2}+\lambda_{i, 1} h_{i, t-1}^{2}+\partial_{i, 1} \varepsilon_{i, t-1}^{2} I_{t-1}$

Here, $h_{i, t}^{2}$ is the conditional variance of individual stock $i$ at time $t$. On the right side of the equation, $\varphi i, b$ represents the unconditional variance associated with the underlying stock $i$ at time $t$, and $\varphi i, c$ is the coefficients term depicting any change in unconditional variance of error term in pre to post period. $D_{\text {fut }}$ is a dummy variable, which takes on the value 1 after the resumption of future contracts, and 0 otherwise. The coefficient $\partial_{i, 1}$ could be interpreted as the impact of recent news on the conditional variance of the prediction errors. $\varepsilon_{i, t-1}^{2}$ is the square of the prediction errors in the preceding time i.e. $t-1$. The coefficient depicts the cumulative impact of past news on the conditional variance at time $t . h_{i, t}^{2}$ represents the lagged conditional variance. The coefficient $\partial_{i, 1}$ depicts the asymmetric impact of news in the preceding session, and is a dummy variable, which takes on the value 1 , if the $\varepsilon_{i, t-1}$ is postive, and 0 if it is negative. Wilcoxon Signed Rank Test (WSRT) is used to compare change in systematic and unsystematic risk from pre to post period of SSFs and Non-SSFs, separately. On the other hand, in order to check that whether change in systematic and unsystematic risk is consistent across SSFs and Non-SSFs; non-parametric Mann-Whitney U Test (MWUT) is used. 


\section{Analysis and Results}

The analysis of the study consists of the estimation of the mean equation for systematic risk, followed by variance equation for unsystematic risk of the model using daily and weekly ${ }^{6}$ data. Table 1 and 3 presents the descriptive statistics (i.e., estimates the skewedness, kurtosis) and results of Jarque-Berra (JB) to check the normality of the residuals series for each SSFs and Non-SSFs. In addition Lagrange multiplier (LM) is employed to check the presence of serial correlation. The existence of heteroscedasticiy is investigated by the use of ARCH test. Table 2 and 4 presents the AR (1) incorporated in the CAPM along with GJR-GARCH $(1,1)$ model for each SSF, separately. Three different probability density functions (Normal, Student's $t$, and

Table 1: Descriptive Statistics of SSFs

\begin{tabular}{|c|c|c|c|c|c|c|c|c|}
\hline & \multicolumn{4}{|c|}{ Residuals } & \multicolumn{2}{|c|}{ LM test } & \multirow{2}{*}{\multicolumn{2}{|c|}{$\frac{\text { Residuals }}{\text { ARCH test }}$}} \\
\hline & $\begin{array}{c}\text { Skew- } \\
\text { ness }\end{array}$ & Kurtosis & \multicolumn{2}{|c|}{ Normality test } & F-test & Prob & & \\
\hline \multicolumn{9}{|l|}{ Scrip } \\
\hline AJI & -0.129 & 3.950 & 10.010 & 0.007 & 0.670 & 0.513 & 3.534 & 0.000 \\
\hline AN & 0.318 & 4.741 & 35.498 & 0.000 & 3.543 & 0.030 & 1.956 & 0.039 \\
\hline BAF & 0.147 & 5.381 & 59.469 & 0.000 & 4.518 & 0.012 & 0.734 & 0.692 \\
\hline DGKC & 0.098 & 3.260 & 1.099 & 0.577 & 1.907 & 0.151 & 2.177 & 0.020 \\
\hline $\mathrm{EC}$ & -0.820 & 5.223 & 78.826 & 0.000 & 3.617 & 0.028 & 4.398 & 0.000 \\
\hline FFBQ & 1.007 & 10.701 & 654.740 & 0.000 & 2.476 & 0.086 & 0.475 & 0.905 \\
\hline FFC & 5.514 & 57.308 & 31733.050 & 0.000 & 1.667 & 0.191 & 0.115 & 1.000 \\
\hline $\begin{array}{c}\text { HUB- } \\
\mathrm{CO}\end{array}$ & 0.286 & 7.311 & 195.436 & 0.000 & 0.120 & 0.887 & 0.812 & 0.618 \\
\hline LUCK & -0.219 & 4.196 & 16.754 & 0.000 & 2.712 & 0.068 & 0.838 & 0.592 \\
\hline MCB & 0.465 & 6.332 & 13.640 & 0.000 & 1.028 & 0.359 & 0.313 & 0.977 \\
\hline NBP & 4.277 & 47.955 & 21639.640 & 0.000 & 1.765 & 0.173 & 0.026 & 1.000 \\
\hline NML & -0.182 & 3.103 & 1.470 & 0.479 & 1.677 & 0.189 & 2.423 & 0.009 \\
\hline OGDC & -0.449 & 4.784 & 41.218 & 0.000 & 1.149 & 0.319 & 8.933 & 0.000 \\
\hline POL & -0.055 & 3.985 & 10.156 & 0.006 & 0.446 & 0.641 & 1.375 & 0.193 \\
\hline PPL & 4.058 & 36.199 & 12069.610 & 0.000 & 0.743 & 0.477 & 0.058 & 1.000 \\
\hline
\end{tabular}

6 Descriptive statistics and estimates for mean and variance equations for weekly data could be obtained from the authors of the study 


\begin{tabular}{|c|c|c|c|c|c|c|c|c|}
\hline PSO & -0.052 & 4.060 & 11.716 & 0.003 & 1.180 & 0.309 & 10.202 & 0.000 \\
\hline PTCL & 0.115 & 4.838 & 35.446 & 0.000 & 2.529 & 0.082 & 0.734 & 0.692 \\
\hline UBL & 0.463 & 6.050 & 104.977 & 0.000 & 0.209 & 0.812 & 0.471 & 0.908 \\
\hline
\end{tabular}

Table 1 presents the estimates the skewedness, kurtosis, results of Jarque-Berra (JB) to check the normality of the residuals series for each SSFs. In addition Lagrange multiplier (LM) is employed to check the presence of serial correlation. The existence of heteroscedasticiy is investigated by the use of ARCH test.

GED) are used for each stock, accordingly. The table 2 depicts the coefficients $\left(\propto_{i}, \gamma\right.$ $\left., \beta_{i, b}, \beta_{i, c^{\prime}} \varphi_{i, b}, \varphi_{i, c} \delta_{i, 1}, \lambda_{i, 1} \partial_{i, 1}\right)$ estimated for mean and variance equation. Similarly, Table 4 presents the estimates of the coefficients for Non-SSFs.

\subsection{Estimates of Systematic Risk}

In Table 5, empirical results for the impact of resumption of SSFs on the systematic risk (i.e. beta coefficient) of the CAPM model are presented for daily data. The mean and median of the beta coefficient for the SSFs stocks are 0.9181 and 1.1530, respectively. Also, the mean and median of the change in beta coefficient are 0.0077 and -0.1190 . The non-parametric WSRT identifies that the decrease in systematic risk after the listing of SSFs contracts listings is significantly different from zero. To obtain more vivid picture of changes, the study isolates the behavior of systematic risk changes for each SSF in pre and post periods. Panel A of the table 5 shows that $\beta_{i, c}$ is significant for seven stocks, among which $43 \%$ are positive and remaining $57 \%$ have negative sign. This suggests that more stocks show decrease in systematic risk after the resumption of SSFs.

Panel B of table 5 report the results of Non-SSFs. The mean and median of the beta coefficient and change in beta coefficient for Non-SSFs are 1.0859 and 1.1080, and -0.1939 and -0.1500 , respectively. Moreover, the table 5 also depicts that none of the Non-SSFs stocks show significantly positive change, but 100\% significant beta change showed decrease in the systematic risk. In addition, non-parametric MWUT is used to compare the significance of post listing beta changes in among SSFs and Non-SSFs.

In Table 6, empirical results for the impact of resumption of SSFs on the systematic risk (i.e. beta coefficient) of the CAPM model are presented for weekly data. The mean and median of the beta coefficient for the SSFs stocks are 0.785 and 0.236 , respectively. Also, the mean and median of the change in beta coefficient are 0.625 and -0.238 . The non-parametric WSRT identifies that the decrease in systematic risk after the listing of SSFs contracts listings is significantly different from zero. To obtain more vivid picture of changes, the study isolates the behavior of systematic risk changes for each SSF in pre and post periods. Panel A of the table 5 shows that 


\begin{tabular}{|c|c|c|c|c|c|c|c|c|c|c|c|c|c|c|c|c|c|c|c|}
\hline & $\dot{\vec{m}}$ & 焉 & 㤩 & 㤩 & $\begin{array}{l}\overline{\widetilde{Z}} \\
\bar{\Xi} \\
\mathrm{Z}\end{array}$ & 惫 & 豈 & 疍 & च्ञ & $\begin{array}{l}\text { 焉 } \\
\end{array}$ & 見 & 畕 & 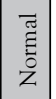 & 㥁 & $\begin{array}{l}\mathrm{A} \\
\mathrm{J} \\
\end{array}$ & 畐 & 푱 & 疍 & 岂 \\
\hline & 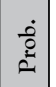 & 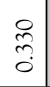 & $\begin{array}{c}\overrightarrow{1} \\
\infty \\
0 \\
0\end{array}$ & $\mid \begin{array}{c}\tilde{f} \\
\tilde{d} \\
\dot{0}\end{array}$ & $\begin{array}{c}\stackrel{a}{+} \\
\stackrel{0}{0}\end{array}$ & $\begin{array}{l}\tilde{\hat{\sigma}} \\
0 \\
0\end{array}$ & $\begin{array}{l} \pm \\
\stackrel{5}{0} \\
0 \\
0\end{array}$ & 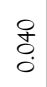 & $\begin{array}{l}F \\
F \\
0 \\
0\end{array}$ & $\begin{array}{l}\tilde{3} \\
0\end{array}$ & $\mid \begin{array}{l}\tilde{f} \\
0 \\
0\end{array}$ & 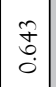 & \begin{tabular}{|c|} 
\\
\multirow{3}{*}{} \\
0
\end{tabular} & $\begin{array}{l}8 \\
\stackrel{0}{0} \\
\stackrel{0}{0}\end{array}$ & \begin{tabular}{|c|} 
\\
\multirow{2}{2}{} \\
0 \\
0
\end{tabular} & \begin{tabular}{|l}
$\vec{\sigma}$ \\
$\dot{0}$ \\
$\dot{0}$
\end{tabular} & $\begin{array}{l}\tilde{\sigma} \\
\tilde{\sigma}\end{array}$ & \begin{tabular}{l}
8 \\
\hdashline \\
0
\end{tabular} & సे \\
\hline & $\begin{array}{c}2 \\
0 \\
0 \\
0^{\prime}\end{array}$ & $\begin{array}{l}0 \\
0 \\
0 \\
0\end{array}$ & $\begin{array}{l}\tilde{0} \\
0 \\
0\end{array}$ & \begin{tabular}{|l|}
$\overrightarrow{\widehat{\sigma}}$ \\
$\dot{0}$ \\
\end{tabular} & $\begin{array}{l}\text { సे } \\
0 \\
\end{array}$ & \begin{tabular}{|l|} 
\\
2 \\
0 \\
0 \\
0 \\
\end{tabular} & 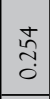 & 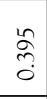 & $\begin{array}{l}\text { छे } \\
\text { ¿े }\end{array}$ & \begin{tabular}{|l|}
$\tilde{0}$ \\
$\dot{0}$ \\
$\dot{0}$
\end{tabular} & \begin{tabular}{|c|}
$\tilde{\Xi}$ \\
0 \\
\end{tabular} & \begin{tabular}{|l|} 
\\
0 \\
0 \\
\\
\end{tabular} & \begin{tabular}{|l|}
0 \\
$o$ \\
0 \\
$\dot{i}$
\end{tabular} & $\stackrel{7}{7}$ & \begin{tabular}{|c|}
$\tilde{b}$ \\
0 \\
0 \\
\end{tabular} & $\begin{array}{l}\tilde{\delta} \\
\dot{\delta} \\
\end{array}$ & $\begin{array}{l}8 \\
0 \\
0 \\
0 \\
\end{array}$ & 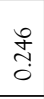 & $\begin{array}{l}\tilde{\delta} \\
\delta \\
0\end{array}$ \\
\hline & 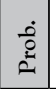 & $\begin{array}{l}\infty \\
\stackrel{0}{0} \\
0\end{array}$ & $\begin{array}{l}8 \\
8 \\
0\end{array}$ & $\begin{array}{l}8 \\
8 \\
\circ\end{array}$ & $\begin{array}{l}8 \\
8 \\
\circ\end{array}$ & \begin{tabular}{|c|} 
\\
$\stackrel{0}{0}$ \\
$\stackrel{0}{0}$
\end{tabular} & $\begin{array}{l}8 \\
8 \\
0\end{array}$ & $\begin{array}{l}8 \\
8 \\
0\end{array}$ & $\begin{array}{l}8 \\
\vdots \\
\circ\end{array}$ & 8 & $\mid \begin{array}{c}\text { in } \\
\stackrel{2}{0} \\
0\end{array}$ & $\begin{array}{l}8 \\
8 \\
0 \\
0\end{array}$ & $\begin{array}{l}8 \\
8 \\
0\end{array}$ & $\begin{array}{l}8 \\
8 \\
0\end{array}$ & $\begin{array}{l}8 \\
8 \\
0\end{array}$ & $\begin{array}{l}8 \\
8 \\
0\end{array}$ & $\begin{array}{l}8 \\
0 \\
0\end{array}$ & $\begin{array}{l}8 \\
8 \\
0\end{array}$ & \begin{tabular}{l}
$\hat{a}$ \\
\multirow{r}{c}{} \\
$\dot{0}$
\end{tabular} \\
\hline c & 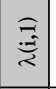 & $\begin{array}{l}\stackrel{\infty}{ } \\
\stackrel{+}{+} \\
0\end{array}$ & $\begin{array}{l}\vec{n} \\
0 \\
0\end{array}$ & \begin{tabular}{|l|} 
\\
\\
\\
\end{tabular} & 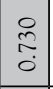 & \begin{tabular}{|c|} 
\\
$\hat{\tilde{n}}$ \\
$\hat{\jmath}$ \\
\end{tabular} & 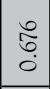 & 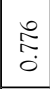 & $\begin{array}{l}n \\
\vdots \\
- \\
\end{array}$ & 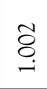 & $\mid \begin{array}{l}\hat{b} \\
\hat{\swarrow} \\
0\end{array}$ & $\mid \begin{array}{c}0 \\
\stackrel{-}{-}\end{array}$ & $\mid$\begin{tabular}{|c}
$\vec{\infty}$ \\
$\infty$ \\
0 \\
0
\end{tabular} & 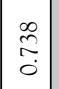 & \begin{tabular}{|l|} 
\\
$\infty$ \\
$\infty$ \\
0 \\
0
\end{tabular} & $\left|\begin{array}{l}0 \\
\vdots \\
\vdots \\
0\end{array}\right|$ & $\begin{array}{c}\overline{\vec{m}} \\
0\end{array}$ & 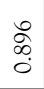 & 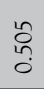 \\
\hline 5 & 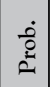 & $\begin{array}{l}\stackrel{y}{\mathcal{Y}} \\
\dot{0}\end{array}$ & $\begin{array}{l}\hat{0} \\
\stackrel{1}{0} \\
0\end{array}$ & $\frac{\tilde{a}}{\grave{O}}$ & $\begin{array}{l}\overrightarrow{\tilde{n}} \\
0\end{array}$ & $\mid \begin{array}{l}0 \\
0 \\
0 \\
0\end{array}$ & $\begin{array}{l}0 \\
0 \\
\dot{0} \\
0\end{array}$ & $\begin{array}{l}8 \\
8 \\
0\end{array}$ & $\begin{array}{l}\stackrel{\infty}{\tilde{T}} \\
\stackrel{0}{0}\end{array}$ & 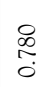 & $\begin{array}{l}8 \\
8 \\
0\end{array}$ & $\left|\begin{array}{l}0 \\
0 \\
0 \\
0\end{array}\right|$ & $\left|\begin{array}{c}0 \\
0 \\
0 \\
0\end{array}\right|$ & \begin{tabular}{|l|}
0 \\
0 \\
0 \\
0
\end{tabular} & $\mid$\begin{tabular}{c} 
\pm \\
\multirow{2}{2}{} \\
0 \\
0
\end{tabular} & $\mid \begin{array}{c}\tilde{\hat{\jmath}} \\
0\end{array}$ & $\mid \begin{array}{l}\tilde{0} \\
0 \\
0\end{array}$ & $\begin{array}{l}8 \\
8 \\
0\end{array}$ & $\begin{array}{l}8 \\
8 \\
0\end{array}$ \\
\hline & $\overrightarrow{0}$ & $\begin{array}{l}\tilde{\tilde{O}} \\
\tilde{\dot{\delta}}\end{array}$ & $\stackrel{\infty}{\Rightarrow}$ & $\begin{array}{l}\tilde{o} \\
\tilde{0} \\
\dot{i}\end{array}$ & $\mid \begin{array}{l}n \\
0 \\
0 \\
0 \\
0\end{array}$ & $\begin{array}{l}\tilde{J} \\
\tilde{O} \\
0\end{array}$ & $\mid \begin{array}{l}\infty \\
\tilde{0} \\
0 \\
0\end{array}$ & \begin{tabular}{|l}
$n$ \\
$\tilde{0}$ \\
$\dot{i}$
\end{tabular} & $\begin{array}{l}8 \\
\vdots \\
\circ\end{array}$ & $\begin{array}{l}n \\
\vdots \\
0 \\
0\end{array}$ & $\mid \begin{array}{l}0 \\
0 \\
0 \\
0 \\
0\end{array}$ & $\begin{array}{l}\tilde{0} \\
0 \\
\dot{Q}\end{array}$ & \begin{tabular}{|c|}
$\overrightarrow{7}$ \\
0
\end{tabular} & $\begin{array}{l}0 \\
\stackrel{2}{0} \\
0\end{array}$ & \begin{tabular}{|l|} 
\\
\\
0 \\
0
\end{tabular} & $\mid \begin{array}{l}2 \\
0 \\
\dot{i} \\
\end{array}$ & 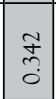 & $\begin{array}{l}\text { oे } \\
\text { Q }\end{array}$ & $\begin{array}{l}\frac{ \pm}{5} \\
\dot{0} \\
\dot{0}\end{array}$ \\
\hline & $\begin{array}{c}\dot{0} \\
2 \\
2 \\
2\end{array}$ & $\begin{array}{c}\tilde{B} \\
\stackrel{3}{0} \\
\end{array}$ & 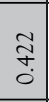 & $\begin{array}{l}\infty \\
\infty \\
0 \\
0 \\
0\end{array}$ & \begin{tabular}{|l}
$\vec{F}$ \\
$\tilde{O}$ \\
0
\end{tabular} & \begin{tabular}{|l|}
$\vec{\jmath}$ \\
$\dot{0}$
\end{tabular} & 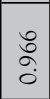 & \begin{tabular}{|l|l}
$\infty$ \\
$\infty$ \\
0 \\
0
\end{tabular} & $\begin{array}{l}\text { f } \\
\text { t. } \\
0\end{array}$ & $\stackrel{\circ}{\circ}$ & 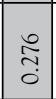 & $\mid \begin{array}{c}\vec{\sigma} \\
0 \\
0 \\
0\end{array}$ & 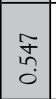 & \begin{tabular}{|l|} 
\\
2 \\
0 \\
0 \\
\end{tabular} & $\left|\begin{array}{c}n \\
\tilde{y} \\
0\end{array}\right|$ & \begin{tabular}{|c|}
$\overrightarrow{0}$ \\
0 \\
0
\end{tabular} & $\left|\begin{array}{|c}\infty \\
\vdots \\
\vdots \\
0\end{array}\right|$ & \begin{tabular}{l}
$\widetilde{F}$ \\
\multirow{0}{0}{}
\end{tabular} & \begin{tabular}{l}
$2 n$ \\
\multirow{2}{f}{} \\
0
\end{tabular} \\
\hline$\sim$ & 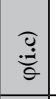 & \begin{tabular}{l}
8 \\
\hdashline \\
0
\end{tabular} & $\begin{array}{l}8 \\
8 \\
0 \\
\end{array}$ & $\begin{array}{l}8 \\
8 \\
0 \\
\end{array}$ & $\begin{array}{l}8 \\
8 \\
0 \\
\end{array}$ & $\begin{array}{l}8 \\
8 \\
0 \\
\end{array}$ & \begin{tabular}{|l|}
8 \\
0 \\
0 \\
\end{tabular} & \begin{tabular}{|l}
8 \\
8 \\
0 \\
\end{tabular} & $\begin{array}{l}8 \\
\vdots \\
\end{array}$ & \begin{tabular}{|l|} 
\\
8 \\
0 \\
\end{tabular} & $\begin{array}{l}8 \\
8 \\
0\end{array}$ & $\begin{array}{l}8 \\
8 \\
0 \\
\end{array}$ & \begin{tabular}{|l|}
8 \\
8 \\
0 \\
\end{tabular} & \begin{tabular}{|l|} 
\\
\\
\\
\end{tabular} & \begin{tabular}{|l|} 
\\
8 \\
\\
\end{tabular} & \begin{tabular}{|l|} 
\\
8 \\
0 \\
0 \\
\end{tabular} & \begin{tabular}{|l|} 
\\
8 \\
0 \\
\end{tabular} & $\begin{array}{l}8 \\
8 \\
0\end{array}$ & $\begin{array}{l}8 \\
8 \\
0 \\
\end{array}$ \\
\hline$I$ & 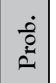 & 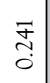 & $\underset{\tilde{N}}{\mathbb{N}}$ & $\mid \begin{array}{l}n \\
\tilde{0} \\
0 \\
0\end{array}$ & $\begin{array}{l}\tilde{z} \\
0\end{array}$ & \begin{tabular}{|l|l}
$\infty$ \\
0 \\
$\vdots$ \\
0
\end{tabular} & 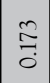 & $\mid \begin{array}{l}\mid \\
\delta \\
0 \\
0\end{array}$ & $\mid \begin{array}{l}1 \\
\infty \\
0 \\
0 \\
0\end{array}$ & $\begin{array}{l}a \\
\stackrel{0}{0} \\
0\end{array}$ & $\mid$\begin{tabular}{c}
1 \\
\multirow{2}{a}{} \\
0
\end{tabular} & $\mid$\begin{tabular}{l}
0 \\
\multirow{0}{0}{} \\
0 \\
0
\end{tabular} & $\left|\begin{array}{c}0 \\
0 \\
0 \\
0\end{array}\right|$ & \begin{tabular}{l|}
$\vec{F}$ \\
$\dot{0}$
\end{tabular} & 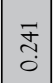 & 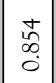 & $\mid \begin{array}{l}n \\
\tilde{o} \\
0 \\
0\end{array}$ & 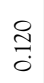 & \begin{tabular}{l}
0 \\
\multirow{1}{f}{} \\
$\dot{0}$
\end{tabular} \\
\hline i & 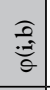 & $\begin{array}{l}8 \\
8 \\
\circ \\
\end{array}$ & $\begin{array}{l}8 \\
8 \\
0 \\
\end{array}$ & \begin{tabular}{|l|} 
\\
8 \\
0 \\
\end{tabular} & $\begin{array}{l}8 \\
8 \\
0\end{array}$ & $\begin{array}{l}8 \\
8 \\
0\end{array}$ & $\begin{array}{l}8 \\
8 \\
0\end{array}$ & $\begin{array}{l}8 \\
8 \\
\end{array}$ & $\begin{array}{l}8 \\
8 \\
0\end{array}$ & $\begin{array}{l}8 \\
8 \\
0\end{array}$ & $\mid \begin{array}{l}8 \\
8 \\
0 \\
\end{array}$ & \begin{tabular}{|l|}
8 \\
8 \\
0 \\
0
\end{tabular} & $\mid \begin{array}{l}8 \\
8 \\
0\end{array}$ & $\begin{array}{l}8 \\
8 \\
0 \\
\end{array}$ & $\mid \begin{array}{l}8 \\
8 \\
0\end{array}$ & $\begin{array}{l}8 \\
8 \\
0 \\
\end{array}$ & \begin{tabular}{|l|}
8 \\
8 \\
0
\end{tabular} & $\begin{array}{l}8 \\
8 \\
0 \\
0\end{array}$ & ৪ \\
\hline & $\begin{array}{l}\dot{0} \\
\stackrel{0}{0} \\
\stackrel{2}{2}\end{array}$ & $\begin{array}{l}\infty \\
\stackrel{8}{0} \\
\stackrel{2}{0}\end{array}$ & $\begin{array}{l}0 \\
0 \\
0 \\
0 \\
0\end{array}$ & \begin{tabular}{|l|}
$\hat{y}$ \\
0 \\
0 \\
0
\end{tabular} & $\begin{array}{c}n \\
\hat{0} \\
0\end{array}$ & $\begin{array}{l}0 \\
\dot{8} \\
\dot{0}\end{array}$ & $\begin{array}{l}8 \\
8 \\
0\end{array}$ & \begin{tabular}{|l|}
8 \\
8 \\
0 \\
\end{tabular} & 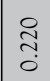 & 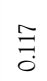 & $\left|\begin{array}{c}\tilde{\Xi} \\
0 \\
0\end{array}\right|$ & \begin{tabular}{|c|c}
$\tilde{0}$ \\
$\tilde{0}$ \\
0
\end{tabular} & $\mid$\begin{tabular}{l}
$\hat{0}$ \\
\multirow{2}{0}{}
\end{tabular} & $\begin{array}{l}8 \\
8 \\
0\end{array}$ & $\mid \begin{array}{c}\tilde{0} \\
0 \\
0\end{array}$ & $\mid \begin{array}{c}\tilde{0} \\
\widetilde{T} \\
0\end{array}$ & $\begin{array}{l}8 \\
8 \\
0\end{array}$ & $\begin{array}{l}\tilde{\hat{0}} \\
0 \\
0\end{array}$ & $\frac{ \pm}{ \pm}$ \\
\hline$\approx$ & 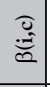 & $\tilde{\delta}$ & $\frac{\tilde{q}}{\dot{q}}$ & 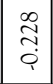 & $\begin{array}{l}0 \\
\stackrel{0}{0} \\
\dot{Q}\end{array}$ & $\begin{array}{c}\tilde{\bar{m}} \\
\bar{Q}\end{array}$ & $\begin{array}{c}\tilde{\hat{\alpha}} \\
\hat{i}\end{array}$ & $\begin{array}{l}\stackrel{+}{\checkmark} \\
\dot{q} \\
\dot{Q}\end{array}$ & $\begin{array}{l}\Xi \\
\end{array}$ & $\begin{array}{l}\tilde{I} \\
\tilde{Q}\end{array}$ & 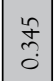 & \begin{tabular}{|c|}
$\infty$ \\
$\vdots$ \\
0 \\
0
\end{tabular} & 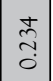 & $\mid \begin{array}{c}\tilde{2} \\
\tilde{\partial} \\
0\end{array}$ & $\mid \begin{array}{c} \pm \\
\infty \\
\\
\\
\end{array}$ & $\begin{array}{l}\overrightarrow{\vec{Z}} \\
\vec{Q}\end{array}$ & $\stackrel{g}{g}$ & $\begin{array}{l}\overrightarrow{3} \\
0 \\
0\end{array}$ & 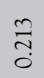 \\
\hline & $\begin{array}{l}\dot{0} \\
\dot{0} \\
2\end{array}$ & $\begin{array}{l}8 \\
8 \\
0\end{array}$ & $\begin{array}{l}8 \\
8 \\
0\end{array}$ & \begin{tabular}{|l|}
8 \\
8 \\
0 \\
\end{tabular} & $\begin{array}{l}8 \\
8 \\
0\end{array}$ & $\begin{array}{l}8 \\
8 \\
0\end{array}$ & $\begin{array}{l}8 \\
8 \\
0\end{array}$ & $\begin{array}{l}8 \\
8 \\
0 \\
\end{array}$ & 8 & 8 & $\mid \begin{array}{l}8 \\
8 \\
0\end{array}$ & $\mid \begin{array}{l}8 \\
\vdots \\
0 \\
0\end{array}$ & $\mid \begin{array}{l}8 \\
8 \\
0\end{array}$ & $\begin{array}{l}8 \\
8 \\
0 \\
\end{array}$ & $\mid \begin{array}{l}8 \\
8 \\
0\end{array}$ & $\begin{array}{l}8 \\
8 \\
0\end{array}$ & $\begin{array}{l}8 \\
8 \\
0\end{array}$ & $\begin{array}{l}8 \\
8 \\
\end{array}$ & $\begin{array}{l}8 \\
8 \\
0 \\
0\end{array}$ \\
\hline & $\begin{array}{l}\hat{0} \\
\overrightarrow{0} \\
\overrightarrow{0}\end{array}$ & $\begin{array}{l}\infty \\
\stackrel{\infty}{-} \\
\stackrel{-}{-}\end{array}$ & $\stackrel{\text { P }}{\rightarrow}$ & $\begin{array}{c}\tilde{a} \\
\stackrel{\vec{\sigma}}{\sigma}\end{array}$ & 啇 & $\stackrel{\sim}{\stackrel{2}{=}}$ & 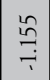 & $\begin{array}{l}n \\
\vdots \\
\dot{\sigma}\end{array}$ & 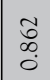 & 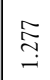 & 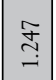 & 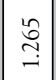 & $\stackrel{゚}{\stackrel{\overbrace{}}{\leftrightarrows}}$ & $\left|\begin{array}{l}2 \\
\stackrel{2}{0} \\
0\end{array}\right|$ & 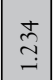 & $\mid \begin{array}{c}\vec{\pi} \\
0 \\
0\end{array}$ & $\mid \begin{array}{l}8 \\
8 \\
0 \\
0\end{array}$ & 宅 & 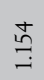 \\
\hline & $\begin{array}{l}\dot{0} \\
\stackrel{0}{0} \\
0\end{array}$ & $\begin{array}{l}8 \\
\varnothing \\
0\end{array}$ & $\tilde{8}$ & \begin{tabular}{|l|} 
\\
0 \\
0 \\
0
\end{tabular} & $\begin{array}{l}\tilde{8} \\
\dot{0}\end{array}$ & \begin{tabular}{|l|l}
$\infty$ \\
0 \\
0 \\
0
\end{tabular} & $\mid \begin{array}{l}\hat{n} \\
\hat{0} \\
0\end{array}$ & $\begin{array}{l}8 \\
8 \\
0 \\
\end{array}$ & 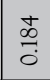 & $\begin{array}{l}\tilde{\hat{o}} \\
0 \\
0\end{array}$ & $\mid \begin{array}{l}\mid \\
\tilde{8} \\
0 \\
0\end{array}$ & $\mid$\begin{tabular}{l|} 
\\
0 \\
0 \\
0 \\
0
\end{tabular} & $\mid \begin{array}{l}0 \\
0 \\
0 \\
0\end{array}$ & \begin{tabular}{|l|} 
\\
$\vdots$ \\
0 \\
\end{tabular} & $\left|\begin{array}{l}\tilde{\sigma} \\
\tilde{0} \\
0\end{array}\right|$ & $\begin{array}{l}8 \\
8 \\
0\end{array}$ & $\mid \begin{array}{l}\infty \\
\infty \\
i \\
0 \\
0\end{array}$ & 8: & ஜ̂̊ి \\
\hline & $>$ & $\frac{+}{0}$ & $\frac{2}{0}$ & \begin{tabular}{|l|l}
$\tilde{0}$ \\
0 \\
0
\end{tabular} & $\stackrel{\infty}{\stackrel{2}{0}}$ & \begin{tabular}{|l}
$\mid$ \\
$\hat{\delta}$ \\
0 \\
0
\end{tabular} & $\begin{array}{l}2 \\
0 \\
0 \\
0\end{array}$ & $\mid$\begin{tabular}{l|}
$\vec{n}$ \\
$\overrightarrow{0}$
\end{tabular} & \begin{tabular}{l}
8 \\
\hdashline \\
\hdashline \\
$\dot{0}$
\end{tabular} & $\begin{array}{l}\tilde{O} \\
0 \\
0\end{array}$ & $\mid \begin{array}{l}0 \\
\\
0\end{array}$ & $\mid \begin{array}{c}\overrightarrow{5} \\
0 \\
0\end{array}$ & $\mid \begin{array}{c}n \\
\stackrel{2}{0} \\
0\end{array}$ & $\begin{array}{l}\stackrel{0}{0} \\
\stackrel{0}{0}\end{array}$ & $\mid$\begin{tabular}{l}
2 \\
\multirow{2}{f}{} \\
0 \\
0
\end{tabular} & 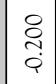 & \begin{tabular}{l}
$\tilde{2}$ \\
\multirow{0}{*}{} \\
0
\end{tabular} & $\stackrel{\substack{0 \\
0 \\
0}}{0}$ & $\frac{2}{\infty}$ \\
\hline & 일 & $\begin{array}{l}\infty \\
\stackrel{0}{0} \\
\\
0\end{array}$ & $\begin{array}{c}\tilde{D} \\
\tilde{0} \\
\hat{0}\end{array}$ & \begin{tabular}{|l|} 
\\
0 \\
0 \\
0 \\
\end{tabular} & $\begin{array}{l}0 \\
\check{\delta} \\
\vdots\end{array}$ & \begin{tabular}{|l|} 
\\
\\
$\dot{0}$
\end{tabular} & $\begin{array}{l}\widetilde{J} \\
\widetilde{0} \\
\end{array}$ & $\begin{array}{l} \pm \\
0 \\
0\end{array}$ & 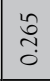 & $\overrightarrow{5}$ & $\left|\begin{array}{r}8 \\
8 \\
\infty \\
0\end{array}\right|$ & \begin{tabular}{|l|}
$\mid n$ \\
0 \\
0 \\
0
\end{tabular} & $\mid \begin{array}{l}\tilde{z} \\
\vdots \\
0\end{array}$ & $\begin{array}{l}\tilde{f} \\
\tilde{f} \\
0 \\
0\end{array}$ & $\mid \begin{array}{l}\tilde{2} \\
\tilde{0}\end{array}$ & $\begin{array}{l}\tilde{n} \\
0 \\
0\end{array}$ & \begin{tabular}{|l|}
8 \\
8 \\
0
\end{tabular} & 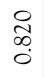 & $\begin{array}{l}\grave{\alpha} \\
\text { ò }\end{array}$ \\
\hline & $8^{-1}$ & $\begin{array}{l}\vec{\delta} \\
\dot{0}\end{array}$ & $\begin{array}{l}\overrightarrow{8} \\
\dot{0}\end{array}$ & 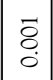 & $\begin{array}{l}8 \\
8 \\
0\end{array}$ & $\begin{array}{l}\tilde{\delta} \\
\delta \\
\end{array}$ & $\begin{array}{l}8 \\
8 \\
0\end{array}$ & $\begin{array}{l}8 \\
\vdots \\
0 \\
\end{array}$ & ৪ & $\vec{\delta}$ & $\mid \begin{array}{l}8 \\
8 \\
0\end{array}$ & 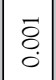 & $\mid \begin{array}{l}8 \\
8 \\
0\end{array}$ & \begin{tabular}{l}
8 \\
\hdashline \\
$\circ$
\end{tabular} & $\mid \begin{array}{l}8 \\
8 \\
0\end{array}$ & ৪ & $\begin{array}{l}\bar{\sigma} \\
\dot{i}\end{array}$ & $\begin{array}{l}8 \\
8 \\
0\end{array}$ & ৪ \\
\hline & $\begin{array}{l}\overrightarrow{\overrightarrow{0}} \\
\dot{m}\end{array}$ & $\overline{\mathrm{Z}}$ & Z & 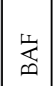 & 莺 & 㞻 & $\mid \begin{array}{l}0 \\
0 \\
\text { 蛋 }\end{array}$ & \begin{tabular}{|c|c}
0 \\
至
\end{tabular} & 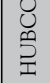 & U. & $\frac{0}{2}$ & 苇 & $\sum_{z}$ & $\begin{array}{l}0 \\
0 \\
0\end{array}$ & $\overrightarrow{0}$ & $\tilde{a}$ & 2 & & $\supset$ \\
\hline
\end{tabular}

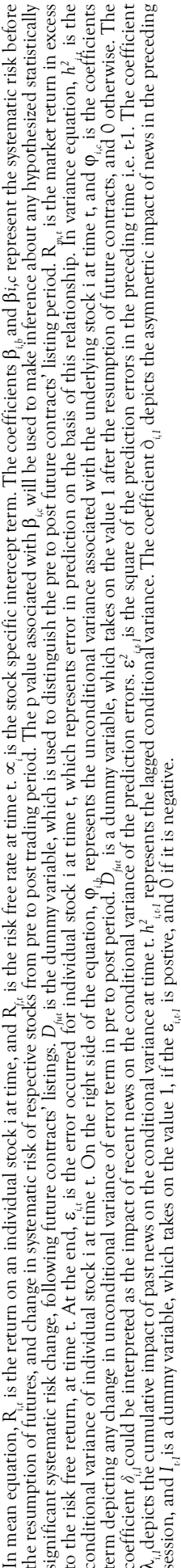


Table 3: Descriptive Statistics for Non-SSFs

\begin{tabular}{|c|c|c|c|c|c|c|c|c|}
\hline & \multicolumn{4}{|c|}{ Residuals } & \multicolumn{2}{c|}{ LM test } & \multicolumn{2}{c|}{ Residuals } \\
\hline Stocks & $\begin{array}{c}\text { Skew- } \\
\text { ness }\end{array}$ & $\begin{array}{c}\text { Kurto- } \\
\text { sis }\end{array}$ & \multicolumn{2}{|c|}{ Normality test } & F-test & Prob & \multicolumn{2}{c|}{ ARCH test } \\
\hline ABL & 0.383 & 4.866 & 42.043 & 0.000 & 0.259 & 0.772 & 2.045 & 0.030 \\
\hline ACBL & 1.898 & 16.920 & 2151.180 & 0.000 & 2.104 & 0.124 & 0.493 & 0.894 \\
\hline APL & 5.243 & 84.891 & 70432.560 & 0.000 & 11.748 & 0.000 & 1.990 & 0.035 \\
\hline ARL & 11.325 & 160.068 & 260226.900 & 0.000 & 1.419 & 0.244 & 0.770 & 0.658 \\
\hline BAHL & 7.392 & 93.822 & 87495.490 & 0.000 & 1.226 & 0.295 & 0.006 & 1.000 \\
\hline DHC & -0.244 & 3.944 & 11.677 & 0.003 & 0.299 & 0.742 & 2.812 & 0.003 \\
\hline EFU & 0.008 & 2.758 & 0.608 & 0.738 & 1.002 & 0.369 & 0.899 & 0.535 \\
\hline FCCL & -0.301 & 5.591 & 73.101 & 0.000 & 2.919 & 0.056 & 3.202 & 0.001 \\
\hline HBL & 3.806 & 44.916 & 18754.080 & 0.000 & 1.102 & 0.334 & 0.021 & 1.000 \\
\hline KAPC & 0.211 & 3.949 & 11.141 & 0.000 & 0.338 & 0.713 & 1.280 & 0.242 \\
\hline KTM & -0.680 & 4.425 & 40.100 & 0.000 & 2.138 & 0.120 & 2.913 & 0.002 \\
\hline MGCL & 10.204 & 141.218 & 201714.900 & 0.000 & 0.033 & 0.968 & 0.006 & 1.000 \\
\hline MLCF & -0.595 & 8.476 & 324.537 & 0.000 & 0.063 & 0.939 & 1.140 & 0.333 \\
\hline NCL & -0.336 & 2.978 & 4.668 & 0.097 & 3.421 & 0.034 & 1.524 & 0.132 \\
\hline NRL & -0.384 & 4.622 & 33.275 & 0.000 & 2.138 & 0.120 & 1.175 & 0.309 \\
\hline TELE & 0.195 & 18.042 & 2339.493 & 0.000 & 0.520 & 0.595 & 2.312 & 0.013 \\
\hline
\end{tabular}

Table 3 presents the estimates the skewedness, kurtosis, results of Jarque-Berra (JB) to check the normality of the residuals series for each Non-SSFs. In addition Lagrange multiplier (LM) is employed to check the presence of serial correlation. The existence of heteroscedasticiy is investigated by the use of ARCH test.

$\beta_{i, c}$ is significant for 9 stocks. Panel B of table 5 report the results of Non-SSFs. The mean and median of the beta coefficient and change in beta coefficient for NonSSFs are 1.031 and 1.028 , and -0.625 and -0.238 , respectively. Moreover, the Table 5 also depicts that none of the Non-SSFs stocks show significantly positive change, but $100 \%$ significant beta change showed decrease in the systematic risk. In addition, non-parametric MWUT is used to compare the significance of post listing beta changes in among SSFs and Non-SSFs.

The findings strongly suggest that there is no evidence of changes in systematic risk because of the SSFs contracts' listings but may be some other sector, industry or macroeconomic factors. The findings of this study regarding impact of impact of SSFs listings on systematic risk of underlying stocks are consistent with the results of Mazouz and Bowe (2006) and Khan (2006). 


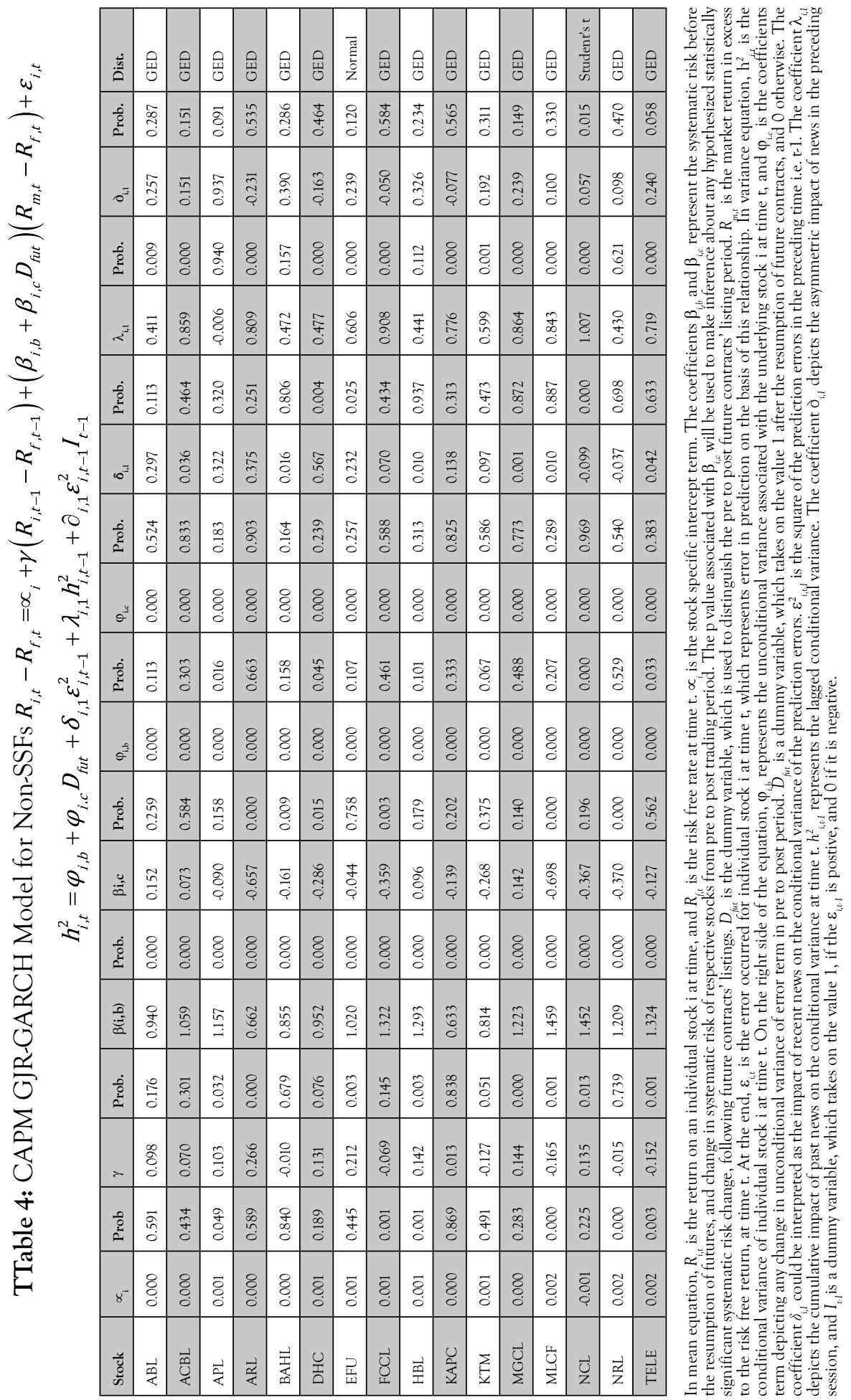


Table 5: The Impact of Future Trading on the Systematic Risk of the Underlying Stock: CAPM approach (Daily Data)

\begin{tabular}{|c|c|c|}
\hline & Panel A: SSFs & Panel B: Non-SSFs \\
\hline Mean (Median) & & \\
\hline$\beta_{i, b}$ & $0.9181(1.153)$ & $1.086(1.108)$ \\
\hline$\beta_{i, c}$ & $0.0077(-.119)$ & $-.194(-.150)$ \\
\hline WSRT Z value (P-value) & $-3.195(0.001)$ & $-3.516(0.000)$ \\
\hline Number of stocks with 5\% significant $\beta_{i, b}$ & 18 & 16 \\
\hline Number of stocks with 5\% significant $\beta_{i, c}$ & 7 & $16(0)$ \\
\hline $5 \%$ Significantly positive (negative) $\beta_{i, b}$ & $17(1)$ & $0(6)$ \\
\hline $5 \%$ Significantly positive (negative) $\beta_{i, c}$ & $3(4)$ & \\
\hline MWUT Z value (P-value) & \multicolumn{2}{|c|}{$0.000(1.000)$} \\
\hline
\end{tabular}

Table 6: The Impact of Future Trading on the Systematic Risk of the Underlying Stock: CAPM approach (Weekly Data)

\begin{tabular}{|c|c|c|}
\hline & Panel A: SSFs & Panel B: Non-SSFs \\
\hline Mean (Median) & & \\
\hline$\beta_{i, b}$ & $0.785(0.236)$ & $1.031(1.028$ \\
\hline$\beta_{\mathrm{i}, \mathrm{c}}$ & $0.625(-.238)$ & $-.256(-.260)$ \\
\hline WSRT Z value (P-value) & $-2.356(0.001)$ & $-2.352(0.005)$ \\
\hline Number of stocks with 5\% significant $\beta_{\mathrm{i}, \mathrm{b}}$ & 18 & 16 \\
\hline Number of stocks with 5\% significant $\beta_{\mathrm{i}, \mathrm{c}}$ & 9 & $16(0)$ \\
\hline 5\% Significantly positive (negative) $\beta_{\mathrm{i}, \mathrm{b}}$ & $16(2)$ & $0(7)$ \\
\hline 5\% Significantly positive (negative) $\beta_{\mathrm{i}, \mathrm{c}}$ & $4(5)$ & \\
\hline MWUT Z value (P-value) & \multicolumn{2}{|c}{$0.10(0.990)$} \\
\hline
\end{tabular}

\subsection{Estimate of Un-systematic Risk}

Table 7 reports the findings of the impact of resumption of SSFs on the unconditional variance of stochastic error term of the underlying stocks. The results are based upon the estimates computed from the error series of the mean equation (i.e., CAPM) of the model. The change in un-systematic risk is measured through introduction of a dummy variable in the variance equation i.e. GJR-GARCH $(1,1)$ of the model. The coefficient in variance equation captures the change in the unsystematic risk after the resumption of SSFs. In Table 6, Panel A depicts the mean and median of un-systematic risk and change in the un-systematic risk. The mean and median of unsystematic risk $\varphi_{i, b}$ are $1.96 \mathrm{E}-5$ and 6.4E-6, respectively. Similarly, the mean and 
median of change in unsystematic risk $\varphi_{i, c}$ are $-1.15 \mathrm{E}-5$ and $-2.25 \mathrm{E}-6$, respectively. The results indicate that change in the un-systematic risk is negative after the resumption of SSFs. The Z-value computed from WSRT i.e. -3.289 confirms that there is a significant decrease in the un-systematic risk.

Table 8 reports the findings of the impact of resumption of SSFs on the unconditional variance of stochastic error term of the underlying stocks for weekly data. The results are based upon the estimates computed from the error series of the mean equation (i.e., CAPM) of the model. The change in un-systematic risk is measured through introduction of a dummy variable in the variance equation i.e. GJR-GARCH $(1,1)$ of the model. The coefficient $\varphi_{i, c}$ in variance equation captures the change in the unsystematic risk after the resumption of SSFs. In Table 8, Panel A depicts the mean and median of un-systematic risk and change in the un-systematic risk. The mean and median of unsystematic risk $\varphi_{i, b}$ are $1.325 \mathrm{E}-4$ and $6.4 \mathrm{E}-6$, respectively. Similarly, the mean and median of change in unsystematic risk $\varphi_{i, c}$ are $-1.965 \mathrm{E}-4$ and $-2.008 \mathrm{E}-5$, respectively. The results indicate that change in the un-systematic risk is negative after the resumption of SSFs. The Z-value computed from WSRT i.e. -3.001 confirms that there is a significant decrease in the un-systematic risk.

The identified decrease in the unsystematic risk after the listing of SSFs contracts could be attributed to several potential factors. These can be related to (1) measurement bias; (2) market of industry wide macroeconomic conditions; or (3) or the reduction in trading noise after the resumption of future contracts. The reduction in the trading noise may lead to efficient incorporation and reflection of information to the stock prices. To be able to identify one of the above mentioned reasons, the study makes use of the control sample. The comparison of change in the unsystematic risk of SSFs and Non-SSFs may lead to find out the reasons other than SSFs listings. Panel B in table 6 depict the mean and median of both $\varphi_{i, b}$ and $\varphi_{i, c}$. The mean and median of $\varphi_{i, b}$ are 3.01E-5 and 1.79E-5. On the other hand, mean and median of $\varphi_{i, c}$ are -1.07E-5 and $-5.75 \mathrm{E}-6$, respectively. The descriptive depict that the change in unsystematic risk after the resumption of SSFs are negative for Non-SSFs control sample. Moreover, MWT show that there is no significant difference in the change in the unsystematic risk between SSFs and Non-SSFs after SSFs contracts' listings. This means that the change in unsystematic risk cannot be attributed to SSFs listings but other sector, industry or macroeconomic factors. Panel B in Table 8 depict the mean and median of both $\varphi_{i, b}$ and $\varphi_{i, c}$. The mean and median of $\varphi_{i, b}$ are 2.118E-3 and 1.321E-4. On the other hand, mean and median of $\varphi_{i, c}$ are $-1.025 \mathrm{E}-4$ and $-3.256 \mathrm{E}-6$, respectively. The descriptive depict that the change in unsystematic risk after the resumption of SSFs are negative for Non-SSFs control sample. Moreover, MWT show that there is no significant difference in the change in the unsystematic risk between SSFs and Non-SSFs 
after SSFs contracts' listings. This means that the change in unsystematic risk cannot be attributed to SSFs listings but other sector, industry or macroeconomic factors.

The findings of this study regarding impact of SSFs on unsystematic risk are consistent with the results of Mazouz and Bowe (2006), Spyrou (2005), Gulen and Mayhew (2000) and Lee and Oh (1992). The results are in contradiction to the results of McKenzie, Brailsford and Faff (2001) who report decrease in systematic risk and unsystematic risk. They assert that regulations are costly and inappropriate. Further, the results are also in contrast to the findings of Martin and Senchak (1989) and Damodaran (1990). There could be several reasons for the results of this study from others (e.g., market microstructure differences between developing and developed markets,

Table 7: The Impact of Future Trading on the Unsystematic Risk of the Underlying Stock: GJR-GARCH approach (Daily Data)

\begin{tabular}{|c|c|c|}
\hline & Panel A: SSFs & Panel B: Non-SSFs \\
\hline Mean (Median) & & \\
\hline$\varphi_{i, b}$ & $1.963 \mathrm{E}-5(6.400 \mathrm{E}-6)$ & $3.012 \mathrm{E}-5$ (1.795E-5) \\
\hline$\varphi_{\mathrm{i} . \mathrm{c}}$ & $-1.157 \mathrm{E}-5(-2.250 \mathrm{E}-6)$ & $-1.070 \mathrm{E}-5(-5.750 \mathrm{E}-6)$ \\
\hline WSRT Z value (P-value) & $-3.289(.001)$ & $-2.741(.006)$ \\
\hline Number of stocks with 5\% significant $\varphi_{\mathrm{i}, \mathrm{b}}$ & 3 & 5 \\
\hline Number of stocks with 5\% significant $\varphi_{\mathrm{i} . \mathrm{c}}$ & 2 & 0 \\
\hline $5 \%$ Significantly positive (negative) $\varphi_{\mathrm{i}, \mathrm{b}}$ & $3(0)$ & $0(0)$ \\
\hline $5 \%$ Significantly positive (negative) $\varphi_{\mathrm{i} . \mathrm{c}}$ & $1(1)$ & \\
\hline MWUT Z value (P-value) & \multicolumn{2}{|c}{$-.052(.959)$} \\
\hline
\end{tabular}

Table 8: The Impact of Future Trading on the Unsystematic Risk of the Underlying Stock: GJR-GARCH approach (Weekly Data)

\begin{tabular}{|c|c|c|}
\hline & Panel A: SSFs & Panel B: Non-SSFs \\
\hline Mean (Median) & & \\
\hline$\varphi_{i, b}$ & $1.325 \mathrm{E}-3(6.400 \mathrm{E}-6)$ & $2.118 \mathrm{E}-3$ (1.321E-4) \\
\hline$\varphi_{\mathrm{i} . \mathrm{c}}$ & $-1.965 \mathrm{E}-4(-2.008 \mathrm{E}-5)$ & $-1.025 \mathrm{E}-4$ (-3.256E-6) \\
\hline WSRT Z value (P-value) & $-3.001(.009)$ & $-2.325(.008)$ \\
\hline Number of stocks with 5\% significant $\varphi_{\mathrm{i}, \mathrm{b}}$ & 5 & 8 \\
\hline Number of stocks with 5\% significant $\varphi_{\mathrm{i} . \mathrm{c}}$ & 3 & 0 \\
\hline 5\% Significantly positive (negative) $\varphi_{\mathrm{i}, \mathrm{b}}$ & $5(0)$ & $0(0)$ \\
\hline 5\% Significantly positive (negative) $\varphi_{\mathrm{i} . \mathrm{c}}$ & $2(1)$ & \\
\hline MWUT Z value (P-value) & \multicolumn{2}{|c}{$-.165(.336)$} \\
\hline
\end{tabular}


lack of program trading activities, stringent regulations of SSFs, conservative approach of SECP for selection of SSFs, distinction of SSFs, Options, index and USFs etc.

\section{Conclusion and Policy Implications}

This study investigates the impact of resumption of SSFs with stringent regulations on risk characteristics of the underlying stocks in the context of an emerging economy. The study contributes to the literature by adding AR (1) term to CAPM augmented GJR-GARCH $(1,1)$ model for measurement of systematic and unsystematic risk, and use of student's t, GED along with normal distribution. In order to check the impact of SSFs contracts' listings on underlying stock, a sample comprised of 18 SSFs along with a carefully constructed control sample of 16 Non-SSFs is used to avoid the endogenity bias. Employment of control sample methodology helps in isolating the impact of resumption of equity derivatives from other potential factors. The study attempt to identify that whether this observed change (decrease) in the SSFs listings' firms systematic and unsystematic risk could be attributed to the SSFs contract listings' event or not. A comprehensive analysis of the findings suggest that the change (decrease) in the systematic risk and unsystematic risk measured from the unconditional variance of error term could not be attributed to the SSFs listings, but can be explained by the market, industry or macroeconomic wise fluctuations. Specifically, the results suggest that SSFs have had no impact on systematic and unsystematic risk. Overall, the results are in line with some of the earlier studies (Malik \& Shah, 2016; Malik \& Shah, 2014; Malik, Shah, \& Khan, 2013; and Malik \& Khan, 2012) which employ different techniques.

From the empirical results, it could be interpreted that the resumption of SSFs with stringent regulations has either helped in mitigating the destabilizing ability of SSFs or there are no such effects of SSFs. Any such effects can be studied in future studies.

Since, futures are in their infancy stage in Pakistan, and regulations for options contracts are in process, our findings might have implications for both of them. However, our findings should be interpreted carefully. There is a possibility that futures have no destabilizing effect on spot market as our results suggest; however, it is also possible that SECP is too conservative in its approach of selection of stocks for SSF and chalking out stringent regulations for trading in SSFs, thereby limiting the role of SSFs to destabilize the market. These two alternative explanations for no-destabilizing effect of SSFs on spot market in KSE can be explored in future research studies. Such an analysis is important because if SSFs do not destabilize the market, then unnecessary stringent regulations do no good, instead they limit much needed liquidity of the market. 


\section{References}

Ahmad, H., Shah, S. Z. A., \& Shah, I. A. (2010). Impact of futures trading on spot price volatility: Evidence from Pakistan. International Research Journal of Finance and Economics, 59, 145-165.

Becketti, S., \& Roberts, D. J. (1990). Will increased regulation of stock index futures reduce stock market volatility? Economic Review, 75(6), 33-46.

Becketti, S., \& Roberts, D. J. (1990). Will increased regulation of stock index futures reduce stock market volatility? Economic Review, 75(6), 33-46.

Beine, M., Laurent, S., \& Lecourt, C. (2002). Accounting for conditional leptokurtosis and closing days effects in FIGARCH models of daily exchange rates. Applied Financial Economics, 12(8), 589-600.

Bessembinder, H., \& Seguin, P. J. (1992). Futures】trading activity and stock price volatility. The Journal of Finance, 47(5), 2015-2034.

Board, J., Sandmann, G., \& Sutcliffe, C. (2001). The effect of futures market volume on spot market volatility. Journal of Business Finance $\mathcal{E}$ Accounting, 28(7-8), 799-819.

Black, F. (1986). Noise. The Journal of Finance, 41(3), 529-543.

Bollerslev, T. (1987). A conditionally heteroskedastic time series model for speculative prices and rates of return. The Review of Economics and Statistics, 69(3), 542-547.

Brorsen, B. W. (1991). Futures trading, transaction costs, and stock market volatility. Journal of Futures markets, 11(2), 153-163.

Brown-Hruska, S., \& Kuserk, G. (1995). Volatility, volume and notion of balance in the S\&P500 cash and futures markets. Journal of Futures Markets, 15(6), 193-227.

Butterworth, D. (2000). The impact of futures trading on underlying stock index volatility: The case of the FTSE Mid 250 contract. Applied Economics Letters, 7(7), 439-442.

Chang, E. C., Cheng, J. W., \& Pinegar, J. M. (1999). Does future trading increase stock market volatility? The case of the Nikkei stock index futures markets. Journal of Banking and Finance, 23(5), 727-753.

Conrad, J. (1989). The price effect of option introduction. The Journal of Finance, 44(2), 487-498.

Damodaran, A. (1990). Index futures and stock market volatility. Review of Futures Markets, 9(2), 442-457.

Damodaran, A., \& Lim, J. (1991). The effects of option listing on the underlying stocks' return processes. Journal of Banking E⿱ Finance, 15(3), 647-664.

De Long, B. J., Shleifer, A., Summers, L. H., \& Waldman, R. J. (1990a). Noise trader risk in financial markets. Journal of Political Economy, 98(4), 703-738.

Demsetz, H. (1968). The cost of transacting. Quarterly Journal of Economics, 82(1), 33 - 53.

Dennis, S. A., \& Sim, A. B. (1999). Share price volatility with the introduction of individual share 
futures on the Sydney Futures Exchange. International Review of Financial Analysis, 8(2), 153-163.

Easley, D., \& O' hara, M. (1987). Price, trade size, and information in securities markets. Journal of Financial economics, 19(1), 69-90.

Edwards, F. R. (1988). Does futures trading increase stock market volatility? Financial Analysts Journal, 44(1), 63-69.

Elfakhani, S., \& Chaudhury, M. (1995). The volatility effect of option listing: Some Canadian evidence. The Quarterly Review of Economics and Finance, 35(1), 97-116.

Ellueca, E. J., \& Lafuente, A. (2003). The effect of spot and futures trading on stock index market volatility: A nonparametric approach. The Journal of Futures Markets, 23(9), 841-862.

Figlewski, S. (1981). Futures trading and volatility in the GNMA futures. Journal of Finance, 36(2), 445 $-456$.

Glosten, L. R., \& Milgrom, P. R. (1985). Bid, ask and transaction prices in a specialist market with heterogeneously informed traders. Journal of Financial Economics, 14(1), 71-100.

Gorton, G., \& Pennacchi, G. (1993). Security baskets and index-linked securities. Journal of Business, 66(1), $1-27$.

Gulen, H., \& Mayhew, S. (2000). Stock index futures trading and volatility in international stock market. Journal of Futures Markets, 20(7), 661-685.

Gupta, O. P., \& Kumar, M. (2002). Impact of introduction of index futures on stock market volatility: The Indian experience. Presented at the Pacific Basin Finance, Economics, and Accounting Conference 2002, Nanyang Technological University, Singapore.

Harris, L. (1989). S\&P 500 cash stock price volatilities. Journal of Finance, 44(5), 1155-1175.

Hussain, A., Obaid, Z., \& Afridi, S. (2011). Testing of CAPM in an emerging economy: A case study of Paksitan. Business and Economic Review, 3(2), 143-153.

Hodgson, A., \& Nicholls, D. (1991). The impact of index futures on Australian share-market volatility. Journal of Business Finance $\mathcal{E}$ Accounting, 18(2), 267-280.

Kaiser, T. (1996). One-factor-GARCH models for German stocks: Estimation and forecasting. Available at SSRN: http://ssrn.com/abstract $=1063$

Khan, S., \& Hijazi, T. (2009). Single stock futures trading and stock price volatility: Empirical analysis. The Pakistan Development Review, 48:4(Winter), 553-563.

Khan, S. U. (2006). Role of the futures market on volatility and price discovery of the spot market: Evidence from Pakistan's stock market. Lahore Journal of Economics, 11(2), 107-121.

Khan, S. U., \& Abbas, Z. (2013). Does equity derivatives trading affect the systematic risk of the underlying stocks in an emerging market: Evidence from Pakistan's futures market. Lahore Journal of 
Economics, 18(1), 63-80.

Khan, S., Shah, A., \& Abbas, Z. (2011). Impact of single stock futures trading on stock price volatility of underlying stocks: Empirical evidence from Pakistan's stock market. Journal of Basic and Applied Scientific Research, 1(11), 2000-2008.

Kyriacou, K., \& Sarno, L. (1999). The temporal relationship between derivatives trading and spot market volatility in the U.K.: Empirical analysis and Monte Carlo evidence. Journal of Futures Markets, 19(3), 245-270.

Lee, S. B., \& Ohk, K. Y. (1992). Stock index futures listing and structural change in time-varying volatility. Journal of Futures Markets, 12(5), 493-509

Ma, C., \& Rao, R. (1988). Information asymmetry and option trading. The Finance Review, 23(1), 39-51.

Malik, I. R., \& Shah, A. (2016). The impact of SSFs on market efficiency and volatility: A dynamic CAPM approach. Emerging Markets Finance and Trade, (just-accepted).

Malik, I. R., \& Khan, S. (2012). Gains and costs associated with introduction of equity derivatives: Empirical evidence from Pakistan. Presented in the eighth conference of Asia-Pacific Association of Derivatives (APAD).

Malik, I. R., \& Shah, A. (2014). Investor behavior and futures markets: A dynamic CAPM augmented GJR-GARCH process approach with non-normal distributions. Pakistan Journal of Applied Economics, 24(2), 121-142.

Malik, I. R., Shah, A., \& Khan, S. U. (2013). Single stock futures trading and its impact on feedback trading and volatility: A case study of Pakistan. Forman Journal of Economic Studies, 9, 81-107.

Mazouz, K., \& Bowe, M. (2006). The volatility effect of futures trading: Evidence from LSE traded stocks listed as individual equity futures contracts on LIFFE. International Review of Financial Analysis, 15(1), $1-20$.

Madhavan, A. (2000). Market microstructure: A survey. Journal of Financial Markets, 3(3), $205-$ 258.

Martin, J. D., \& Senchak, A. J. (1989). Program trading and systematic stock price behavior. Financial Analyst Journal, 45(3), 61-67.

McKenzie, M. D., Brailsford, T. J., \& Faff, R. W. (2001). New insights into the impact of the introduction of futures trading on stock price volatility. Journal of Futures markets, 21(3), 237-255.

Nelson, D. B. (1991). Conditional heteroskedasticity in asset returns: A new approach. Econometrica: Journal of the Econometric Society, 59(2) 347-370.

Santoni, G. J., (1987). Has programmed trading made stock prices more volatile? Federal Reserve Bank Review, 18-29. 
Schwert, G. W. (1990). Stock market volatility. Financial Analysts Journal, 46(3), 23-34.

Skinner, D. J. (1989). Options markets and stock return volatility. Journal of Financial Economics, 23(1), $61-78$

Smith Jr, C. W. (1989). Market volatility: and Causes and consequences. Cornell Law Review, 74(5), 953-962.

Spyrou, S. I. (2005). Index futures trading and spot market volatility evidence from an emerging market. Journal of Emerging Market Finance, 4(2), 151-167.

Stein, J. C. (1987). Informational externalities and welfare-reducing speculation. The Journal of Political Economy, 95(6), 1123-1145.

Thenmozhi, M. (2002). Futures trading, information and spot price volatility of NSE-50 index futures contract. NSE Research Paper, NSE India.

Vijh, M. A. (1994). S\&P trading strategies and stock betas. The Review of Financial Studies, 7(1), 215-251.

Yang, J., Balyeat, R. B., \& Leatham, D. J. (2005). Futures trading activity and commodity cash price volatility. Journal of Business Finance and Accounting, 32(1-2), 297-323. 
